\title{
Influence of Conciliation Dispute Resolution Mechanism on Sustainable Conflict Resolution in Bungoma County, Kenya
}

\author{
Atemi Amele Justin \\ P.O Box 1087, Bungoma, Kenya
}

\begin{abstract}
Conciliation is a process in which the parties to a dispute, with the assistance of a neutral person, identify the disputed issues. Conciliation is the process by which one or more independent person selected by the parties to an agreement generally by mutual consent, either at the time of making the agreement or subsequently when a dispute has arisen between them, to bring about a settlement of their dispute through consensus between the parties by employing various persuasive and other similar techniques. This study sought to establish the influence of conciliation dispute resolution mechanism on sustainable conflict resolution in Bungoma county, Kenya. The study focused on identifying the various types of conflicts in Lwandanyi,Webuye and Cheptais SubCounties and the factors influencing the adoption of Alternative Dispute Resolution Mechanisms with specific focus on mediation. The study explored the place of ADR in conflict resolution and the extent to which ADR is utilized by leaders. The sample size was comprised of grass root leaders. Simple random sampling and stratified random sampling methods were used to pick the required sample size for the study from the targeted population. The required data was collected using questionaires and interview schedules. The study found that leaders in Bungoma County appreciate and make use of ADR mechanisms in conflict resolution. Mediation mechanism was commonly cited as being used by leaders in addressing various forms of conflict. The study also found that land disputes are the commonest of all conflicts. This was attributed to historical land injustices especially in Mt. Elgon region where politicization of land allocations in the former white settler farms has led to long standing conflict between the Bukusu and the Sabaot communities. The study also revealed that most land disputes were arising due to lack of land ownership documents and rampant corruption at the lands' ministry was blamed for this state of affairs. Based on the study findings, it was recommended that the National and County governments take decisive action to address the land grievances of the Sabaot community to stop the inter clan fighting and leaders be trained and equipped with skills and competencies necessary for conflict resolution.
\end{abstract}

Keywords: Conciliation, Dispute Resolution Mechanism, Sustainable Conflict Resolution

DOI: $10.7176 / \mathrm{JAAS} / 74-04$

Publication date:July $31^{\text {st }} 2021$

\subsection{Background}

Dispute resolution refers to the processes by which disputes are brought to an end (Algert \& Watson, 2002). Dispute is an open disagreement between two or more entities such as people, groups of people, ethnicities, nations, states and cultures who have different interests, goals and or values. Dependent on the intensity of the disagreement the dispute may gradually become a confrontation and finally a conflict. Dispute resolution can occur through three ways; negotiated outcome, where the parties concerned sort out things themselves: mediated outcome, where the parties use the services of an independent mediator to help them arrive at their own agreement and an arbitrated or adjudicated outcome, where an independent arbitrator or court determines how the dispute is to be resolved and makes a binding decision or order to this effect (Algert \& Watson, 2002).

Alternative Dispute Resolution (ADR) is the general name given to a variety of procedures available to parties in civil cases to resolve their disputes before a formal trial (Lambert \& Myers, 1999). Alternative Dispute Resolution refers to processes for resolving disputes other than litigation. Alternative dispute resolution (ADR) mechanisms have existed for thousands of years. Alternative dispute resolution (ADR) refers to any process or collection of processes established to resolve disputes without trial or violence. The term ADR is often used to refer to a broad category of ADR processes such as negotiation, conciliation, mediation, settlement conferences, arbitration, consensus building, and community conferencing.

The primary motivations for ADR are to save money and control risk. Preparing for trial is extremely expensive, and parties can save money if they can resolve the case without having to incur the expense of trial preparation (Barrett \& Barrett, 2004). Also, when parties settle cases, they have some control over the outcome of the case in that they can negotiate for terms of the settlement. If a lawsuit goes to trial, the outcome of the case is left entirely in the hands of the judge or jury. Parties cannot control the risk of losing at trial. ADR gives parties a chance to control that risk. In some cases, privacy or confidentiality may be a factor. Most litigants think of ADR as private, and thus, if they seek secrecy, they may be motivated to try ADR.

Deferent types of Alternative Dispute Resolution incude arbitration, negotiation, mediation, adjudication, family group conferences, expert determination and case evaluation. In mediation, a neutral third party helps the parties come to an agreement about how to resolve the case (Barrett, \& Barrett, 2004). The mediator has no 
authority to impose a solution on the parties. Instead, he goes back and forth between sides to help them come to an understanding about how the case could be resolved to their mutual satisfaction. A mediator can be helpful in helping parties evaluate their case realistically, as the mediator can point out which facts or arguments he believes or rejects (Barrett, \& Barrett, 2004). When courts order parties to try ADR, they most often order mediation. Non-mediated settlement is the process where the parties negotiate with each other without the help of a third party to come to a mutually satisfactory resolution of the case. This process is not ordered or overseen by a court and, therefore, is a private, rather than public, process.

The idea of Alternative Dispute Resolution (ADR) is about the search for and application of "nonconventional" peaceful means of settling dis putes and resolving conflict situations using the least expensive methods, and in ways that satisfy the parties, as well as ways that preserve relationship diplomatically after a settlement might have been reached by the two parties (Hornby, 2006). ADR is specially meant to serve as an alternative to the official or conventional means of settling disputes, mainly through litigation and the courts, but with a preference for non-violence.

\subsubsection{Bungoma County}

Bungoma County is located in western and constitutes of Eight constituencies namely Mt Elgon, Kimilili, Webuye,Webuye North, Sirisia,Kabuchai, Kanduyi and Bumula. The capital of Bungoma County is Bungoma Town. It has a Total Population of 1,375,063 and covers an area of 3,032.2 sq. km. The Population density is 453.5 people per sq. $\mathrm{km}$ and $53 \%$ of the population live below the poverty line. The economy of Bungoma County is mainly agricultural, centering on the sugarcane and maize industries. The area experiences high rainfall throughout the year, and is home to several large rivers, which are used for small-scale irrigation.

Over the years Bungoma County has witnessed numerous conflicts ranging from land clashes in the Mt Elgon region, political violence linked to electoral processes, domestic violence, conflicts related to business transactions as well as labor unrest just to mention but a few. Investigation of the influence of the utility component of Alternative Dispute Resolution strategies will help inform sustainability of conflict resolution efforts (Chesi, 2012). Also, land conflicts has affected Mt. Elgon District in Bungoma county of Kenya. These land conflicts have had far reaching negative effects on the certainty of land markets, tenure and food security, economic production and reduction of poverty. Often, the land conflicts lead to; civil strife, loss of lives, population displacement, destruction of property and international humanitarian crisis (Chesi , 2012).

\subsection{Statement of the problem}

Without timely, accessible, affordable, and trusted mechanisms to resolve differences, localized disagreements or crimes can degenerate into broader conflict (Algert, 1996). This contributes to cultures of violence and vigilante justice. There are recurrent conflicts despite efforts being put in place to address such conflict. The court systems are overwhelmed by a backlog of cases and have systemic challenges being brought about by corruption, poor infrastructure and inaccessibility that work to kill their efficiency. The choice of a good alternative dispute resolution strategy is a difficult task, because a lot of physical and mental energy is required (David, 2006). It is apparent that the success of a functional alternative dispute resolution strategy depends on good application using appropriate method which can subsequently motivate parties in dispute in their various communities. Lack of good alternative dispute resolution strategy by a trained individual in our community and institution can lead to inappropriate behavior and frustration. In making choice of alternative dispute resolution strategies communities are faced with the challenges of selecting the method suitable for achieving non (David, 2006).

Chesi (2012) did a study on the factors influencing land related conflicts in MT. Elgon District, Bungoma County. The study findings established that the severity of land conflicts in Mt. Elgon district is high and currently appear to be associated with geographical land boundaries, political boundaries, political environment and evictions from the land that they stay in. No study had been done on the influence of utilization of alternative dispute resolution mechanisms by leaders on sustainable conflict resolution in Kenya hence a research gap. This study therefore sought to investigate the influence of conciliation dispute resolution mechanism on sustainable conflict resolution in Bungoma County, Kenya.

\subsection{Objective of the study}

The specific objective of the study was;

To establish the influence of conciliation dispute resolution mechanism on sustainable conflict resolution in Bungoma County, Kenya.

\subsection{Research Question}

The study sought to answer the following question;

How does conciliation dispute resolution mechanism affect sustainable conflict resolution in Bungoma County, Kenya? 


\subsection{Significance of the Study}

This research is vital to the conflict resolution teams in Bungoma County because it provides an insight on the utilization of alternative dispute resolution mechanisms by leaders on sustainable conflict resolution. The teams will be able acquire knowledge on the best approach to conflict resolution.

The results of this research are important to the Government of Kenya in the development of rules and procedures of solving conflicts arising within the country. Through the findings of this study, the policy makers can learn various ways in which they may need to handle conflict resolution and hence come up with policies that lead to sustainable conflict management and resolution.

The results of this study will greatly benefit the victims of conflicts in Bungoma County. It will increase awareness on the benefits of embracing Alternative Dispute Resolution Mechanisms and contribute to quick, timely and affordable administration of justice.

Future researchers will also be able to use the research findings as a benchmark to their research on conflict resolution. In addition, the findings of this study will serve as a source of reference in future research. The study has also suggested other areas where future researchers can further their knowledge.

\subsection{Literature Review}

This section discusses past studies on utilization of alternative dispute resolution mechanisms by leaders on sustainable conflict resolution.

\subsubsection{Empirical Review}

According to Uwazie (2011) the notion of ADR fits comfortably within traditional concepts of African justice, particularly its core value of reconciliation. Pioneering ADR projects in Ghana, Ethiopia and Nigeria have generated positive results and illustrate the suitability of ADR in African contexts.Under these arrangements, ADR was used as the default resolution method. Formal court litigation, or instances where the judge actually judges, are reserved for cases of constitutional or legal interpretation, where there is a need to set precedence, in cases with major public policy implications,or as a last resort after ADR has been tried.

\subsubsection{Conciliation Dispute Resolution Mechanism}

Conciliation is a process in which the parties to a dispute, with the assistance of a neutral person, identify the disputed issues. Conciliation is the process by which one or more independent person(s) selected by the parties to an agreement generally by mutual consent, either at the time of making the agreement or subsequently when a dispute has arisen between them, to bring about a settlement of their dispute through consensus between the parties by employing various persuasive and other similar techniques (Fisher, Ury and Patton, 1991). Conciliation is a process similar to mediation but the neutral third party takes a more interventionist role in bringing the two parties together. In the event of the parties are unable to reach a mutually acceptable settlement, the conciliator issues a recommendation which is binding on the parties unless it is rejected by one of them (Fisher, Ury and Patton, 1991). While the conciliator may have an advisory role on the content of the dispute or the outcome of its resolution, it is not a determinative role. A conciliator does not have the power to impose a settlement. It is a process of confidence and faith.

This is a voluntary and informal process by which the parties to a dispute reach a mutually acceptable agreement. As the name implies the parties seek out the best options for each other which culminates in an agreement (Umunadi, 2011). At their option, the process may be private. In this process, they may or may not use counsels and there is no limit to the argument, evidence and interests, which may be canvassed.

The conciliator will help you and the other parties to look at the strengths and weaknesses of each other's arguments. Usually, the conciliator is an expert on the subject of the dispute and as a result, the conciliator may have an advisory role on the content of the dispute or the outcome of its resolution, but not a determinative one. Sometimes, and in some systems it is also called mediation. There may be technical or legal differences between the two expressions, namely, conciliation and mediation, but for the present purpose the expression "conciliation' is used to re fer to both the processes, namely, the conciliation and mediation. Conciliation is an effective means of alternative dispute resolution and can be usefully deployed for both international as well as domestic disputes, except that in the conciliation of an international dispute certain facts assume greater importance than they would in a domestic conciliation (Blake et. al., 2011).

\subsubsection{Theoretical framework}

Various theorists have come up with theories on dispute resolution. The theories adopted by this study include theory of process pluralism, theory of conflict and General Theory on Conflicts and Disputes. Theory of process pluralism points out that different kinds of matters may require different kinds of procedures or ways of dealing with the underlying conflict (Ralf, 1958) theory of conflict attempts to understand the different sources of conflict, the dynamics of how conflict develops, escalates or declines, and how conflict can be managed, reduced or resolved. Conflict theory tries to explain the types of conflicts that exist and whether they are productive or destructive and then goes on to attempt to explain the ways in which conflict proceeds or is structured and how it can be managed or resolved. The General Theory on Conflicts and Disputes assigns disputes to transitional and 
mature democracies and conflicts to authoritarian regimes (Otomar and Wehr, 2001). The First Premise of the General Theory is that there are no conflicts in democratic society, only disputes. The Second Premise is that in authoritarian regimes there are only conflicts and politicized systems of settlement, not disputes. The Third Premise is that in international relations, national states can transform conflicts into disputes. Conflicts are those issues that lack a legitimate, reliable, transparent, non-arbitrary forum for the peaceful settlement of differences (Otomar and Wehr, 2001). Disputes, conversely, are pre described as having recognized forums for their expression and resolution that meet the above criteria. In short, conflicts lack a viable containe" for the routine management of differences. A mature theory of dispute-resolution must encompass all institutions and processes - whether legal or non-legal, formal or informal, contemporary or customary - to further the end of settling disputes by smoothing away discords.

\subsection{Research Methodology}

This study adopted a descriptive research design. As noted by Cooper and Schindler (2000) descriptive research design are concerned with addressing the particular characteristics of a specific population of subjects, either at a fixed point in time or at varying times for comparative purposes. As noted by Gill and Johnson (2002), descriptive research design describes characteristics associated with the subject population. By using descriptive research design, the study was able to establish the how of the phenomenon under investigation. The target population of this study comprised of the dispute resolution leaders in Bungoma county. These are Members of County Assembly (MCA), religious leaders, County Commissioners, local chiefs and their assistants, village and clan elders, representatives of aid agencies, representatives of civil society groups, women leaders and leaders of the youth. These leaders were selected because of the role they play in dispute resolution.

The study selected a representative sample of 90 from the target population. Use of a sample enables the study to save cost and time. According to Pamela L.A \& Robert B.S (1995) experienced researchers regard a sample of 100 respondents as the minimum sample size and 1000 as the maximum sample size for large populations. They note that it is seldom necessary to sample more than 10 percent of the population to obtain adequate confidence.

The study used purposive sampling and simple random sampling to select a sample from the target population. Purposive sampling is a method in which elements are chosen based on purpose of the study. In this study purposive sampling was used to pick three Sub-Counties namely; Webuye, Cheptais and Lwandanyi because they are conflict flash points. Simple random was used to randomly sample the leaders in each of the selected Divisions. According to Mugenda and Mugenda (2003), simple random sampling is a sampling technique designed to ensure that every unit of a population has equal chances of being selected in the population. By use of simple random sampling in this study, a representative sample was obtained.

The data collection instruments that were used in this study are questionnaires and checklist of specific questions that were posed to key informants. As noted by Mugenda and Mugenda(1999), questionnaires are appropriate for use when the target population is educated and knowledgeable. The questionnaires were chosen for data collection in this study since the population of the study is well educated and also the questionnaires save on cost and time. The questionnaire designed in this study comprises of two sections. The first part includes the demographic characteristics questions designed to determine the profile of the respondents while part two deals with the identified factors. The questionnaire has both open and close ended questions. The closed ended questions make use of a five point Likert scale where respondents were required to fill according to their level of agreement with the statements. The unstructured questions were used to encourage the respondents to give an indepth response where close ended questions are limiting.

A pilot study was conducted to test for clarity and understanding of questions and also to find out whether the questions yield the answers expected. The researcher selected a pilot group of 5 individuals from the target population.

The study used both face and content validity to ascertain the validity of the questionnaires. Content validity was employed by this study as a measure of the degree to which data collected using a particular instrument represents a specific domain or content of a particular concept.

Reliability was assessed using the split half reliability method. Reliability is said to be stable if it gives consistent results with repeated measurements of the same object with the same instrument. The degree of stability is determined by comparing the results of repeated measurements. The split half method involves scoring two-halves of a test separately for each person and then calculating a correlation coefficient for the two sets of scores. The researcher split the instrument into two halves. The researcher got a coefficient of 0.70 which implies that there is a high degree of data reliability.

Kothari (2004) views data analysis as the whole process, which starts immediately after data collection and ends at the point of interpretation and processing of results. The quantitative data collected using questionnaires and interview schedules will be inspected for completeness, and analysed using Statistical Package for Social Sciences (SPSS v. 21.0). The results were presented in form of tables and graphs. 


\subsection{Findings}

Research findings are presented in this section.

\subsubsection{Questionnaire return rate}

Out of 90 questionaires administered to 90 leaders in three sub counties of the larger Bungoma County, 85 were returned making questionaire return rate to be $94 \%$.

\subsubsection{Demographic information of the respondents}

This study sought information from male and female leaders of diverse age groups. This was aimed at ensuring that all leaders regardless of the age participated in the study.

Table 1: Age of the respondents

\begin{tabular}{lll}
\hline & Frequency & Percent \\
\hline $25-35$ & 6 & 6.7 \\
$35-45$ & 26 & 28.9 \\
$45-55$ & 36 & 40.0 \\
$55-65$ & 21 & 23.3 \\
65 and older & 1 & 1.1 \\
\hline Total & $\mathbf{9 0}$ & $\mathbf{1 0 0 . 0}$
\end{tabular}

The Table shows that $40 \%$ of the respondents were aged between $46-55$ years and that those aged between 36-45 years accounted for $28.9 \%$ of those interviewed. Those aged between $26-35$ years accounted for $6.7 \%$ while those between 56-65 years stood at 23.3\% The leaders who indicated that they were 65 years and above stood at $1.1 \%$ of the entire sample.

In terms of gender, $86.7 \%$ of the interviewed were men while $13.3 \%$ were women. In Luhya ,Teso and Saboat cultures women have not been readily accepted as capable leaders and have therefore been largely excluded from grass root leadership. Most village and clan elders are men hence the small number of women respondents. It is vital to note that the 2010 constitution gives both men and women equal opportunity in all spheres of social,political and economic being of our country. Therefore nobody should be discriminated or denied leadership opportunities on account of their gender. Women must rise to challenge these discriminatory tendencies and play an active role in the leadership of their communities.

Table 2: Gender of the respondents

\begin{tabular}{llll}
\hline & & Frequency & Percent \\
\hline \multirow{2}{*}{ Valid } & Male & 78 & 86.7 \\
& Female & 12 & 13.3 \\
\hline & Total & $\mathbf{9 0}$ & $\mathbf{1 0 0 . 0}$
\end{tabular}

The respondents were asked to indicate their marital status, this was aimed at establishing whether marital status has a bearing on whether an individual is given leadership roles or not including conflict resolution.

Table 3: Marital status of the respondents

\section{Percent}

\section{Frequency}

\begin{tabular}{llll}
\hline Valid & Married & 86 & 95.6 \\
& Single & 4 & 4.4 \\
\hline & Total & $\mathbf{9 0}$ & $\mathbf{1 0 0 . 0}$
\end{tabular}

This study indicates that $95.6 \%$ the respondents are married while a mere $4.4 \%$ are single an indication that the local communities place value on family life and thus require their leaders to be marry before taking on leadership roles. This however, needs to change so that leadership is not pegged on marital status. It is discriminatory and unconstitutional 
The respondents were asked to indicate their level of education, this was aimed at establishing whether education is a factor that hinders people from executing their leadership responsibilities including conflict resolution.

\section{Table 4: Education of the respondents}

\begin{tabular}{llll}
\hline & & Frequency & Percent \\
\hline \multirow{4}{*}{ Valid } & .00 & 1 & 1.1 \\
& Primary & 3 & 3.3 \\
& Secondary & 43 & 47.8 \\
& Tertiary & 33 & 36.7 \\
& University & 10 & 11.1 \\
\hline & & & $\mathbf{1 0 0 . 0}$
\end{tabular}

This study indicates that literacy levels among leaders in Bungoma County is high with $47.8 \%$ of the sampled leaders having attained secondary education,36.7\% had gone through tertiary institutions while holders of university degrees stood at $11.1 \%$. This therefore shows that the leaders have the requisite education and capacity to execute their functions including conflict resolution.

The question on whether the leaders were born and raised in their area of jurisdiction or they immigrated in to the area was also posed to the respondents. This was aimed at ensuring that the respondents understand the area they work in and the conflict issues at hand. $77.8 \%$ of the respondents said they were born and raised in their areas of jurisdiction. $15.6 \%$ of the respondents migrated into their current areas of residence while $2.2 \%$ of the sampled respondents were born in their areas of residence but were raised elsewhere. This is a clear indication that most of the sampled leaders know their areas well and have a grasp of the issues that cause conflict.

From the study it was also established that $80 \%$ of the respondents have lived in their areas of jurisdiction all their lives while $11.1 \%$ indicated that they had lived in their areas of residence for Ten years or more. Only $7.8 \%$ of the responding leaders said they had lived in their areas for more less than five years. The length time lived in area has a bearing on a person's understanding of not just the area and its people but also the issues affecting them.

This question was posed to respondents with a view to establish whether or not they had worked in the public sector as government employees. Experience in the public sector especially in volatile areas gives an officer opportunity to handle and manage conflict. It affords such officers an opportunity to understand conflict resolution including alternative dispute resolution mechanisms. This experience works to equip the officers with knowledge and skills in the execution of their responsibilities to the public.

As shown in Table 5, 50\% of the respondents reported that they have never worked in the public sector as government employees while $44.4 \%$ reported to have worked in the public sector. The $50 \%$ however explained that they are village and clan elders who work alongside public servants especially chiefs and County Commissioners. Five respondents did not answer this question.

Table 5: Whether or not leader had worked in public service

\begin{tabular}{llll}
\hline & & Frequency & Percent \\
\hline \multirow{4}{*}{ Valid } & .00 & 3 & 3.3 \\
& Yes & 40 & 44.4 \\
& No & 45 & 50.0 \\
& 7.00 & 2 & 2.2 \\
\hline & Total & $\mathbf{9 0}$ & $\mathbf{1 0 0 . 0}$
\end{tabular}

The dominant tribes in Bungoma Countyy are the Bukusu and the Sabaot accounting for $70 \%$ and $24 \%$ of the County population respectively.The Kikuyu,Teso,Tachoni and other tribes account for only $6 \%$ of the County population.This percentages explain the antagonism between the Bukusu and Saboat over land ,distribution of jobs and development resources.

In Lwandanyi and Cheptais Sub-Counties,this conflict is pronounced because of these two dominant tribes. The Saboats mainly inhabit the Cheptais area and the greater Mt. Elgon .The Saboat accuse the Bukusu of 
dominating them by taking most of the political and state leadership positions because of their superior population numbers. This fights led to the creation of Mt. Elgon constituency so that the Sabaots can have their own member of parliament to champion their grievances.

The Bukusu on the other hand accuse the Sabaot of alleniating themselves and identifying with the Kalenjin in the Rift Valley a fact that was always visible during elections where the Saboat voted to support the presidential candidate fronted by the Kalenjin community.

Table 6: Intermarriage among communities

\begin{tabular}{llll}
\hline & & Frequency & Percent \\
\hline \multirow{3}{*}{ Valid } & .00 & 2 & 2.2 \\
& Yes & 85 & 94.4 \\
& No & 3 & 3.3 \\
\hline & & & \\
\hline
\end{tabular}

Communities in Bungoma County intermarry freely. 94.4\% of the sampled respondents indicated that there's free intermarriage among tribes residing in their Sub-Counties. A negligible 3.3\% responded to the contrary. However, this has done little to prevent conflict over land resource allocation in the County an indication that there is significant political undertones in the conflicts.

\subsubsection{Inter community conflicts.}

$37.8 \%$ of the respondents indicated that conflict mostly occurs between the Bvukusu and the Sabaot while $2.2 \%$ said the conflict they have witnessed is between the varrious Sabaot clans.23.3\% indicated that there is conflict between the Bukusu and the Tachoni mainly in Webuye Sub-County. The conflict between the Bukusu and the Sabaot mainly occurs in Cheptais and Lwandanyi Sub-Counties. This is so because the two communities have historically occupied these area but the Sabaots have mostly occupied the upper areas of mount Elgon. The conflicts mainly revolve around land and distribution of resources including state jobs. From my discussions with area residents it emerged that the fight between the Bukusu and Sabaots over land is historical in nature. The sabaots were not farmers but hunters and gatherers mainly leaving in caves in the expansive mt. Elgon area while the Bukusu have always been a farming community. After the departure of white settler farmers from the high potential areas of the mountain the Sabaots laid claim to the land sparking of a violent conflict with the Bukusu community.

Government failure to address land problems in the area and political interference in the process also led to fighting between various Sabaot clans. The Moi government issued land to some clans while others were left out of the scheme. This fueled conflict.It is also notable that many Sabaots were evicted from the mt. Elgon forest rendering many as squarters. This also fueled the conflict and led to the formation of the infamous Sabaot land defence force(SLDF) by disgrantled clans to fight for their rights. The S.L.D.F may have been crushed by brute military force but the land grievances still exist and remain unaddressed.

Despite the violent conflict in Mt. Elgon pitting the various Sabaot clans against each other being highlighted in the media and the swift and brutal government response, it is important to note that the Sabaot speak one language and have historically lived in peace. This is why only $2.2 \%$ of the respondents highlighted this conflict.

In this study, $23.3 \%$ of the respondents indicated that there's a conflict between the Bukusu and the Tachoni communities mainly in Webuye Sub- County.My interactions with the local communities in Webuye revealed long standing rivalry between the two communities dating to pre-colonial times. The Tachoni have always accused the Bukusu of deliberate attempts to dominate and lock them out of political leadership.

To reinforce this fact Tachoni clan elders point to the fact that during colonial times a Bukusu chief was imposed on them and this domination was continued after independence when the Bukusu always grabbed the only parliamentary position available because of their superior numbers. The Tachonis have since felt marginalised. To express their disatisfaction,the Tachoni have always sponsered and voted for one of their own in every election. This injustice has since been addressed following the creation of Webuye North Constituency following the revision of constituency boundaries in Kenya just before the 2013 general election that led to the splitting of the former Webuye constituency.

Village elders, clan elders and religious leaders featured prominently in this study because they are readily available and intimately understand the issues that cause conflict in their communities. Village elders, for example, play a crucial role in providing linkage between the community and government structures as well as actively participate in addressing conflict.

Political leaders such as members of parliament and Members of County Assembly though crucial in conflict issues were unavailable and efforts to reach them were futile because of their busy schedule.

Table 7: Leadership position currently held 


\begin{tabular}{lll} 
& Frequency & Percent \\
\hline .00 & 13 & 14.4 \\
clan elder & 15 & 16.7 \\
village elder & 23 & 25.6 \\
county commissioner & 3 & 3.3 \\
Member of county assembly & 6 & 6.7 \\
Civil Society representative & 8 & 8.9 \\
Aid agency representative & 2 & 2.2 \\
Religious leader & 11 & 12.2 \\
Youth Leader & 2 & 2.2 \\
County Rep & 3 & 3.3 \\
14.00 & 1 & 1.1 \\
27.00 & 1 & 1.1 \\
28.00 & 1 & 1.1 \\
57.00 & 1 & 1.1 \\
& & \\
\hline Total & $\mathbf{9 0}$ & $\mathbf{1 0 0 . 0}$
\end{tabular}

The study also sought to find out how long the leaders had served in a bid to establish their understanding of local issues and conflict dynamics in their areas. $40 \%$ of the leaders indicated that they had served for more than 15 years while $20 \%$ and $30 \%$ of the leaders have been in service for 15 years and 10 years respectively. It is clear that the leaders have a clear understanding of the conflict issues in their areas of jurisdiction by virtue of length of service.

\subsubsection{Frequency of Conflict}

Table 8: Frequency of Conflict

\begin{tabular}{lll} 
& Frequency & Percent \\
& 3 & 3.3 \\
\hline 00 & 14 & 15.6 \\
Fairly frequent & 30 & 33.3 \\
Valid Not frequent & 2 & 2.2 \\
Very Frequent & 41 & 45.6 \\
After every electoral cycle & & \\
& & \\
\hline Total & $\mathbf{9 0}$ & $\mathbf{1 0 0 . 0}$
\end{tabular}

The study also sought to establish the frequency of conflicts and as shown in Table 4.4.6, 45.6\% of the respondents reported that conflicts arise after every electoral cycle. $33.3 \%$ of the respondents said the conflicts though present, are not frequent while $15.6 \%$ of the sampled leaders said the conflicts are fairly frequent. In Kenya, elections are always associated with violence and it is not surprising that $45.6 \%$ of the sampled leaders in Bungoma County said the conflicts arise during and after elections. Politicians use violence to influence the outcome of elections.

The frequency of conflict especially around election time is an indication that politics is a major factor in the triggering of conflict in the County. Politicians take advantage of community grievances concerning land and distribution of development resources to whip up emotions and even sponsor violence for personal gain. In my discussion with leaders in the sampled sub- Counties it emerged that prior to elections the Sabaot leaders in $\mathrm{mt}$ Elgon cause tension to trigger mass exodus of the Bukusu so that they do not vote and tilt scales in favour of particular candidates. 


\subsubsection{Adoption of conciliation in conflict resolution}

Table 9: Showing adoption of conciliation in conflict resolution

\begin{tabular}{llll}
\hline & & Frequency & Percent \\
\hline \multirow{2}{*}{ Valid } & .00 & 1 & 1.1 \\
& Yes & 88 & 97.8 \\
& 124.00 & 1 & 1.1 \\
\hline & Total & $\mathbf{9 0}$ & $\mathbf{1 0 0 . 0}$
\end{tabular}

Conciliation has been overwhelmingly adopted as an alternative dispute resolution mechanism in Bungoma County. This is evidenced $98 \%$ confirmation by all the sampled respondents. This question was aimed at establishing whether or not the leaders had adopted this mechanism in their day to day conflict resolution duties.

Table 10: Use of independent person(s) to bring about a settlement of dispute through consensus

\begin{tabular}{llll}
\hline & & & \\
& & Frequency & Percent \\
\hline \multirow{4}{*}{ Valid } & Yes & 1 & 1.1 \\
& & 80 & 88.9 \\
& NO & 6 & 6.7 \\
& 3.00 & 3 & 3.3 \\
\hline & Total & 90 & 100.0
\end{tabular}

The leadership of Bungoma County adopts the use of independent person(s) selected by the parties by mutual consent when a dispute has arisen between them, to bring about a settlement of their dispute through consensus. This was clearly brought out by $89 \%$ of the sampled leaders as shown in the graph above. This is an indicator that alternative dispute resolution mechanisms are appreciated.

The leaders pointed to the existence of councils of elders made of respected citizens in each of the indigenous communities living in the County. These Councils meet from time to time to deliberate on important issues affecting their communities. They are instrumental in conflict resolution so as to avert violent conflict that has in the past led to loss of lives and massive destruction of community assets.

This came out prominently among respondents sampled in Lwandanyi and Cheptais Sub-Counties who said that because of the historical land feuds between the Bukusu and the Sabaot; the Councils of elders of both sides as well as respected religious leaders have always been called upon by political leaders on both sides to handle disputes before they get out of hand.

Table 11: Techniques employed by conciliators

Frequency

\section{Percent}

\begin{tabular}{llll} 
& .00 & 2 & 2.2 \\
& Coercion & 6 & 6.7 \\
Valid & Persuasion & 5 & 5.6 \\
& & & 65.6 \\
& Negotiation & 59 & 1.1 \\
13.00 & 1 & 17.8 \\
23.00 & 16 & 1.1 \\
34.00 & & $\mathbf{9 0 0 . 0}$ \\
\hline
\end{tabular}


Conciliation involves the use of various techniques to resolve conflicts and reach satisfactory agreements for the parties in a dispute. Some of these techniques include persuasion, negotiation and coercion. $66 \%$ and $6 \%$ of the respondents said they widely employ negotiation and persuasion respectively in their conciliation efforts where parties clearly and soberly state their goals and interests (positions) and are advised to embrace the spirit of give and take so as to reach a middle ground on the issues in dispute.

Only $7 \%$ said they used coercion in their conciliation efforts but were quick to add that this was only used when a party was clearly obstructing efforts to reach an agreement. They cited an example where, for example, official land maps showed boundaries yet a party vehemently disregards the authenticity of the maps. In such circumstances such a party is coursed into agreement and may be threatened with sanctions in case he goes against the agreements reached.

\subsubsection{Options for conciliators in event of parties' inability to reach mutually acceptable settlement.}

In conciliation processes it is possible that conciliation efforts may not yield satisfactory outcomes for the parties involved. In such a scenario conciliators have several options that they can take. In this study as indicated in the graph below $56 \%$ of the sampled respondents said that they issue a recommendation which is binding on the parties unless it is rejected by one of them. This is premised on the fact that conciliators are held in high regard by both parties in the dispute as well as their capacity to adjudicate on the matter at hand. $33 \%$ of the sampled leaders reported that they refer the parties to the courts for settlement of their cases in case of failure of conciliation efforts. They however pointed out that they take time to advice the disputants that litigation especially with regard to land is time consuming and expensive. $2 \%$ of the respondents said they sometimes use threats and sanctions to force the parties into agreement. None said they impose a settlement.

This question was aimed at testing understanding and proper use of conciliation in dispute resolution by the leaders in the Bungoma County. The fact that leaders use persuasion and provide recommendations as well as refer the conflicting parties to courts of law is a pointer to the understanding and use of conciliation.

\subsubsection{Conciliators advisory role on the content of the dispute or outcome of its resolution}

Conciliators have a role to play in advising the parties in a conflict about the content of the dispute or the outcome of its resolution. Conciliators take their time to listen to both sides and make objective judgement based on the facts in the matter. Many times they are able to advice the parties not to waste time and resources by going to the courts if the matter can be conclusively addressed out of court. In this study and as indicated in the graph shown above, a convincing $91 \%$ of the sampled leaders reported to playing this advisory role adding that it goes along way in helping speed up the process of conflict resolution. Only $6 \%$ of the sampled leaders thought otherwise urguing that many times they are incapacitated by lack of technical expertise.

\subsubsection{Conciliators imposing a settlement on the conflicting parties}

In this study respondents were asked whether or not they had imposed a settlement on conflicting parties or had witnessed their colleagues do it. This was aimed at testing their understanding of conciliation and its application in dispute resolution. $37 \%$ of the respondents said they had witnessed the imposition of a settlement on disputants while $63 \%$ said they had not witnessed it. This is an indicator that most leaders understand conciliation and appreciate the value of negotiated settlements as opposed to imposed ones which mostly do not stand the test of time. The process of conciliation can take many forms. However the end result of any conciliation effort is always aimed at reaching a mutually agreed settlement. At the option of the parties, the process may be private. This is especially true if the dispute involves business transactions and the disputants are of the view that publicity of the conflict may hurt their businesses.

The parties may or may not use counsels and there is no limit to the argument, evidence and interests, which may be canvassed. This all in the effort to get the best settlement that fits their interests. Counsels are mainly employed in disputes that require technical expertise as well as those that involve considerable amounts of monetary value where there's considerable risk of loss in case of an unfavorable settlement.

The process may also involve instances where the conciliator helps the parties look at the strengths and weaknesses of each other's arguments with the sole aim of reaching a mutually agreed settlement. In other conciliation efforts, the conciliator is an expert on the subject of the dispute and as a result, the conciliator may have an advisory role on the content of the dispute or the outcome of its resolution.

In this study $48 \%$ of the sampled respondents said they often use the process that provides the conciliator with an opportunity to help the parties look at the strengths and weaknesses of each other's arguments. $10 \%$ of the sampled respondents said the conciliators' expert advice on the content of the dispute or the outcome of its resolution is important. Many respondents gave multiple answers as to the conciliation processes adopted by them in the discharge of their duties. However, as shown by the graph above a lot of emphasis is given to assistance by conciliators to disputants to look at strengths and weaknesses in each other's arguments. 
Table: 12: Showing frequency of recurrence of disputes addressed through conciliation.

\begin{tabular}{|c|c|c|}
\hline & Frequency & Percent \\
\hline .00 & 1 & 1.1 \\
\hline $\begin{array}{l}\text { rarely recur } \\
\text { recur every five }\end{array}$ & 62 & 68.9 \\
\hline $\begin{array}{l}\text { years especially } \\
\text { during elections }\end{array}$ & 24 & 26.7 \\
\hline 3.00 & 1 & 1.1 \\
\hline 34.00 & 1 & 1.1 \\
\hline 134.00 & 1 & 1.1 \\
\hline
\end{tabular}

Table 12 shows $69 \%$ of the sampled respondents indicating that disputes addressed through conciliation rarely recur while $27 \%$ of the respondents indicated that conflicts resolved through conciliation recur every five years especially during elections. Those who said the disputes recur every five years especially during elections made reference to community land disputes. These they said are common place between the Bukusu and the Sabaots in Cheptais and Lwandanyi Sub-Counties and are mostly fueled by politicians.

\subsubsection{Disputes resolved through Conciliation}

According to the leaders sampled in this study, land disputes form the bulk of the disputes solved through mediation by leaders in the County accounting for $60 \%$ of the cases. Disputes over sharing of political leadership positions account for $9 \%$ of the cases while disputes arising out of unequal distribution of development resources only account for $7 \%$ of the cases. Other respondents did not answer this question appropriately. However land disputes were clearly identified as being majorly handled through conciliation. A further probe into why the land disputes featured prominently in cases handled by leaders through conciliation revealed that the County had huge chunks of land that had not be registered and lacked ownership title deeds. This the leaders said was the reason for the high number of land disputes. They squarely blamed the government lands ministry for this failure.

When asked why conciliation had taken center stage in land issues the leaders said residents were facing frustration in courts processes that are not only slow but are also expensive. Disputes arising out of unequal distribution of development resources and sharing of state jobs were said to be handled by members of parliament and leaders in senior positions in government and only featured at the grassroots when members of parliament complain publicly at official functions to galvanize support and secure development support for the County.

\subsection{Conclusion}

Alternative dispute resolution mechanisms are an important component in the justice system of a country. They provide opportunity and space for parties in conflict to resolve the issues in contention amicably while avoiding the costs and delays associated with normal court processes.

This study established that though ADR mechanisms are in use at the community level, County governments have not put in place mechanisms to institutionalize ADR. There are glaring capacity gaps that continue to impact on the adoption and use of ADR mechanisms. This must be addressed.

\subsection{Recommendations.}

In order to address land disputes emanating from lack of clear ownership, the lands ministry needs to improve the quality of service delivery to the citizens of Bungoma County. Rampant corruption perpetuated by officers at the lands office was cited as am major stumbling block in acquisition of land title deeds and must be stopped.

Land allocations in the former white settler areas of $\mathrm{mt}$. Elgon have been infiltrated by political interests and this is the root cause of unrest in Mt. Elgon Sub-County. The national and County government must take decisive action to address the land grievances of the Sabaot community to stop the inter clan fighting that has led to loss of many lives and massive destruction of property.

\section{REFERENCES}

Bingham, L. B. (2004). Employment Dispute resolution: The case for mediation. Conflict Resolution Quartely,22(1-2), 145-174.

Bingham, L. B., \& Hallberlin, C. J. (2009). Dispute System Design and Justice in Employment Dispute Resolution: Mediation at the Workplace. Harvard Negotiation Law Review, 14(1), 1-50

Blake, S., Browne, J., \& Stuart S. (2011). A practical approach to alternative dispute resolution. Oxford 
University Press Inc.: New York

Chesi, A. S. (2012). Factors influencing land related conflicts in MT. Elgon District,

Bungoma County. Unpublished MBA thesis University of Nairobi.

Fisher, R., \& William, U.(2011). Getting to yes: Negotiating agreement without giving

In. Penguin Books ltd: London

Hornby A.S. (2006). Oxford Advanced Learner's Dictionary. India: Oxford University Press.

Pamela L. A \& Robert B. S. (1995). The survey research handbook, University of Wisconsin,Madison, $2^{\text {nd }}$ edition,

Kothari, C. R. (2004), Research Methodology: Methods and Techniques. New Delhi: Wiley

Lacity, M., \& Jansen, M. A. (1994). Understanding qualitative data: A framework of text analysis methods. Journal of Management Information Systems, 11, 137-166.

Lambert, J., and Myers, S. (1999). 50 Activities for conflict resolution. Amherst, MA:

HR Development Press.

Liebmann, M. (2000). Mediation in context. Jessica Kingsley Publishers Ltd: London.

Mugenda. O. A. and Mugenda A. G. (1999). Research methods: Quantitative and

Qualitative approaches, Nairobi, Act Press

Ngechu.M. (2004). Understanding the research process and methods. An introduction to research methods. Acts Press, Nairobi

Polkinghorne, D. (1988). Narrative knowing and the human sciences. Albany: State

University of New York Press.

Otomar, J. B., and Wehr, P. (2001). Using Conflict theory. Press syndicate publishers. Network.

Umunadi, E. K. (2011). The Efficacy of Mediation and Negotiation Methods For Dispute

Resolution In Delta State, Sacha Journal of Policy and Strategic Studies, Volume1Number 2, pp. 64-73

Uwazie, E. E. (2011). Alternative Dispute Resolution in Africa: Preventing Conflict and Enhancing Stability. African Security Brief, 1-6.

Zumeta, Z. (2000). Styles of mediation: Facilitative, evaluative, and transformative mediation'. 